\title{
South African Journal of Childhood Education
}

Priorities and Policy-making in South African Education

Guest editors: Nick Taylor and Thabo Mabogoane

Volume 5 Number 2 December 2015 
Orders and correspondence:

Ms Delia Arends

Soweto Campus, Robert Sobukwe Building Room 101

University of Johannesburg

PO Box 524

Auckland Park

2006

South Africa

Tel: 011 559-5102 


\section{Contents}

Editorial

Can pre-grade $\mathrm{R}$ be the stepping stone to social equality in South Africa

What the Annual National Assessments can tell us about learning deficits over the education system and the school career

Examining oral reading fluency among grade 5 rural English Second Language (ESL) learners in South Africa: An analysis of NEEDU 2013

Continuous assessment and matriculation examination marks - An empirical examination

Informing principal policy reforms in South Africa through data-based evidence

The impact of teacher characteristics on student performance: An analysis using hierarchical linear modelling

An overview of Education data in South Africa: an inventory approach

Style guide for manuscripts

University of Johannesburg Research Bursaries
Nick Taylor \&

i

Thabo Mabogoane

Janeli Kotze

1

Servaas

28

van der Berg

Kim Draper \&

Nic Spaull

Debra Shepherd \&

78

Servaas van

der Berg

Gabi Wills

Paula Armstrong

Chris van Wyk

146

171

174 



\section{Editorial}

\section{Policy research comes of age in South Africa}

There are signs that policy-related research in the field of education is coming of age in South Africa. The existence of the present issue of SAJCE is one such sign, and a strong one at that.

At least two factors are implicated in the growth of this kind of research. First, there is the role of government, particularly through the Department of Planning, Monitoring and Evaluation (DPME) in the Presidency, in commissioning research and making available large data sets. This interest derives from the realisation that the best policy intentions are not easily translated into effective programmes, and that careful research is required to identify problems of programme design and implementation. Second is the issue of capacity, which is growing steadily, and here an important stimulus has been the establishment of research chairs involving the Department of Science and Technology, the National Research Foundation, and the corporate sector. Though no restrictions were placed on the submission of papers for the current issue of SAJCE, and while all papers were individually submitted and evaluated for publication, the final contributions all have links with ReSEP (Research on SocioEconomic Policy) at the University of Stellenbosch. They grew out of the Binding Constraints in South African Education research project, which is financially supported by the Programme to Support Pro-Poor Policy Development (PSPPD), a partnership programme between the European Union and the South African Presidency. However, this is by no means the only source of policy-related research in the education field, with an increasing appetite for undertaking or supporting work of this kind being exhibited by government, the universities, NGOs and the corporate sector.

This collection of papers spans the spectrum of schooling phases - from preprimary, through primary and secondary, to the tertiary level - and provides a taste of the myriad dilemmas and decisions facing policy makers and practitioners in shaping and directing the system. The purpose of this editorial is not to systematically summarise the findings of the seven articles featured, but to attempt to distil a set of larger policy implications from the conclusions of the contributors.

While significant progress has been made in the last two decades in addressing the worst aspects of poverty in South Africa, it is clear from the papers in this volume that inequality is the overriding problem in the school system, with $80 \%$ of the population very much poorer and endowed with greatly inferior schooling than the privileged one-fifth. All seven contributions are acutely aware of this problem, using it as starting assumption, telos for policy recommendations, or both.

\section{The quality of pre-Grade $\mathrm{R}$ provision}

What better place to start but at the beginning, with Janeli Kotzé's analysis of the extent to which pre-Grade $\mathrm{R}$ is, or is capable of, ameliorating social inequality in South 
Africa. Her conclusion: not under present circumstances, which are characterised by very rapid quantitative expansion, generally of very poor quality. This brings us face to face with a classic dilemma in making public policy, often posed as a choice between pursuing the goals of equity versus those of efficiency. This is a feature that characterises all levels and spheres of education in the country. Kotzé motivates for the importance of the pre-school phase, drawing from the research literature, which concurs on the critical importance of nutrition and stimulation during the first 1000 days for cognitive and non-cognitive development. Assuming this to be true, then there is a serious challenge for policy makers to intervene to ensure that every learner receives adequate attention. Kotzé's conclusion is that, currently, increasing provision is being achieved at the expense of quality. Besides the trade-off between quantity and quality, the policy maker is also faced with a challenge of silo planning. A major challenge in offering quality education in the pre-Grade $\mathrm{R}$ phase requires that the Departments of Health, Basic Education and Social Development collaborate in order to offer the full suite of interventions needed to have an impact.

A key recommendation of the National Development Plan (NDP) is to expand preschool provision. In order to assess the extent to which this recommendation is being put into effect, the DPME recently commissioned an evaluation of the impact of Grade $\mathrm{R}$ attendance on learner progress through the Foundation Phase. The study concluded that impact was only discernible for children attending Quintile 5 and, to a lesser extent, Quintile 4 schools (Van der Berg, Girdwood, Shepherd et al 2013). Thus, the rapid roll-out of Grade R provision is, in effect, exacerbating inequity if schools themselves are unable to take advantage of the Grade $R$ intervention. Kotzé's study in the present volume extends these findings to the pre-Grade $\mathrm{R}$ phase, providing a great deal of useful detail about the problems of implementation faced at the institutional level.

A second point arising from Kotzé's study that goes beyond the specific context of its phase location is the importance of initial teacher education (ITE) to the quality of provision. This would seem so obvious as to be beyond comment, yet the public debate about schooling seems little concerned with the extent to which ITE adequately equips teachers for effective classroom practice, despite a growing body of evidence to indicate significant shortcomings in this regard.

\section{The growth of educational inequality in the Foundation Phase (FP)}

In the second paper showcased here Servaas van der Berg uses data from the Annual National Assessment (ANA) tests to provide more detail to the familiar bimodal distribution of South African test scores. The paper contains much useful policy advice concerning the improvement of this initiative. In particular, by tracing ANA scores across grades by quintile, he shows that the patterns of inequity seen at school exit level have largely been set by Grade 4, graphically emphasising the urgency of the need to change teaching and learning practices in the Foundation Phase (FP) and earlier.

In support of this finding, Beshartie and Tsotsotso (2015), in their meta-analysis of education interventions in South Africa, show that the effect sizes of programmes 
directed at the FP are significantly higher than those for any other level, indicating the greater impact of interventions in the first three years compared with those in later phases. As Van der Berg points out, had policy makers considered this lesson prior to designing a major intervention for Grade 9 teachers in 2015, costly government interventions might have been better directed towards the early grades than towards exercises such as the ' $1+4$ ' programme currently focused on Grades 8 and 9. The disjunction between research findings and policy decisions signalled by this example raises its head in almost every one of the papers in this issue.

\section{Reading: The 'fulcrum of academics'}

While van der Berg employs graphical depictions of the ANA data over time to provide a new perspective on the most fundamental problem in South African society - socio-economic inequity reproduced by schools - in their contribution Kim Draper and Nic Spaull illuminate the mechanism through which this vicious cycle is achieved. The authors use NEEDU data from 4667 Grade 5 learners in 214 rural schools spread across the country. They show that $41 \%$ of Grade 5 children are reading at a fluency level below 40 words per minute, the threshold below which they cannot understand what they are reading. Almost all of these non-readers ( $88 \%$ ) scored less than $20 \%$ on the comprehension test, while only $6 \%$ of the sample scored above $60 \%$.

This is an important paper for at least three reasons. First, it draws attention to what must be the most urgent priority, not only in the Foundation Phase, but throughout the system, since

[r]eading is the fulcrum of academics, the pivotal process that stabilizes and leverages children's opportunities to success and become reflective, independent learners.

Good, Simmons \& Smith 1998:45, in Draper \& Spaull, present volume

Second, Draper and Spaull's contribution is an outstanding example of collaboration between the public and private sectors, which in turn may be seen as an indication of the growing maturity of policy-focused research in the country.

Third, the authors conclude with two sets of recommendations that amplify and extend some of the NEEDU conclusions (NEEDU 2014a; 2014b). Calling for a programme to develop appropriate norms for assessing reading fluency, particularly for English Second Language (ESL) learners, the authors take further the debate on appropriate reading norms for South African English First Additional Language (EFAL) learners, concluding that a benchmark of 90-100 WCPM in English in Grade 5 in South Africa is a good starting point.

A final policy recommendation made by Draper and Spaull concerns reading pedagogy and how it may be improved. Here the authors illustrate just how far we are from developing, let alone implementing, an effective method for teaching reading and writing in the FP, calling for fundamental research into, and an evidence-based approach to, this quest. Inevitably, the logic of their argument goes back to pose 
fundamental questions to the ITE sector about the extent to which the universities are providing new teacher graduates with the requisite skills in literacy instruction.

\section{Assessment in Grade 12}

Moving the focus to high schools, Debra Shepherd and Servaas van der Berg look at the correlations between learner scores in the National Senior Certificate (NSC) exams and the continuous assessment (CASS) marks allocated by their teachers. The authors find wide discrepancies between the two scores, with a preponderance towards inflated CASS scores, commonly as high as 20 to 30 percentage points above the NSC marks. While much of this is probably due to teachers inflating CASS scores in the hope of improving the performance of their learners, it seems that many teachers simply do not have the requisite grasp of their subjects to pitch their assessment practices to the standards defined by the curriculum. The obvious lessons for policy and practice are that a primary focus in educator professional development should be placed on equipping teachers, school leaders and systems-level officials with the capacity to analyse test scores and utilise the results to improve pedagogy. This is an important reason for retaining the ANA programme as an aid to communicating curriculum standard to teachers and informing the teaching and learning process.

A second policy lesson for the higher education sector implicit in the contributions of both Shepherd and Van der Berg, and Draper and Spaull highlights the growing importance of the technical aspects of assessment, and the need to provide systematic training to instructional leaders and teachers alike in basic psychometric procedures and how they may be used to inform instruction.

\section{The key role of school principals}

There is universal agreement about the importance of leadership to the quality of education provided by a school, whatever the level. This is the issue addressed by Gabi Wills in her examination of the demographic characteristics of the country's principal cohort. She emphasises the importance of making the right choice in selecting a principal: in the context of low levels of principal mobility and high tenure, the leadership trajectory of the average school is established for nearly a decade with each new principal placement. Yet, Wills concedes, research to date has, at best, found a weak relationship between school performance and the quality of school leadership, as measured by means of traditional academic qualifications and years of service of the principal. This finding implies that research indicators and instruments used to assess principal quality do not measure the most important factors contributing to performance. This might be a reason for the inconclusive findings of much of the research literature on school leadership and management. If this is true, then Wills' description of the performance management system for principals as ineffectual is not surprising: if the research literature cannot identify indicators of good practice, then how can we measure performance? The implications of these uncertainties for 
the research community for school leadership are clear: develop a set of indicators of school leadership and management that guide effective practice.

Given the average age of principals (53 years of age in 2012), Wills predicts that large numbers will need to be replaced in the next five to ten years, further underlining the importance of effective recruitment and promotion procedures in building a cohort of good school leaders. Here too, transfer patterns appear to be skewed towards accentuating inequalities, with more competent leaders finding access into the best performing schools. Current policies are ineffective in ensuring that struggling schools are able to attract and incentivise talented leaders to help turn these schools around. In the interests of increasing the quality of leadership provided to schools, Wills strongly supports the National Development Plan proposals to introduce competency-based assessment in the appointment process, and to implement performance management for incumbent school principals.

There has been movement with respect to the first of these proposals, with the Western Cape applying competence testing in the selection of principals since 2012, and expressing confidence in the positive effects of this practice (NEEDU 2014a). There is some debate on this issue in other provinces and the DBE, while the possibility has been raised of reducing the autonomy of schools, and placing greater authority in the hands of the province, in order to combat nepotistic, corrupt or inefficient school management practices. This debate raises important considerations concerning the balance between maximising the devolution of responsibility to the school level in the interests of democracy, on one hand, and curbing corrupt or self-interested behaviour on the part of local leadership, on the other. Whichever way this debate proceeds in future, quality leadership is key to school improvement, and Wills provides useful suggestions for improving the recruitment and management of principals.

\section{Teacher characteristics}

Paula Armstrong quotes Hanushek on one of the few points of agreement among research workers in the complex sector of teachers and teacher education: "[... ] the quality of teachers is the key element to improving student performance" (Hanushek 2009:171, quoted in Armstrong in the present volume). Her project is to identify teacher characteristics - in terms of demography, qualifications and teaching experience that impact on student performance. Working with the SACMEQ data base, it is not surprising that the only factor fitting this description found by Armstrong was teacher age. Survey-type data, on its own, is unlikely to uncover the complexities of school leadership and classroom pedagogy: these are processes that require more nuanced illumination through observational data, in combination with statistical methods. This conclusion raises research questions about how best to measure teacher quality: 'Are we on the right track?' Armstrong asks. Here too, the most likely answer to this question is: apparently not yet.

At the same time, Armstrong's conclusions that younger teachers (age group 19 - 29) perform significantly better on the SACMEQ teacher tests than their older 
peers, and that they are better able to increase the mean performance of students, are very significant. Younger teachers seem better able to elicit better performance from their students, an effect that could be explained in one of two ways. Younger teachers may relate better to their students because they are closer in age to them than their older counterparts. Another possibility is that changes to teacher training may have left teachers trained under the new university-based system better equipped to teach. Armstrong supports the second option, which implies that, since the reorganisation of the initial teacher education terrain in 2003 , newly qualified teachers have received an education better suited to teaching than their older peers who were largely educated in the training colleges.

Armstrong's findings are a very welcome piece of good news for a sector which has had much bad press in recent years, starting in 2008 with Crain Soudien, then head of the University of Cape Town Education Faculty and chair of the Higher Education Quality Council (HEQC) review team, drawing attention to the "desperate state" of literacy and numeracy in the country. Yet, continued Soudien,

$[w]$ e do not $[\ldots]$ have a body of empirical work and theoretical engagement that is able to speak to this situation [...] after almost 50 years of serious research into teaching and learning, we cannot say, without qualification, what works and what does not.'

Soudien 2008:7

Shortly after the conference where Soudien made this statement, the HEQC published its wide-ranging - and largely negative - review of programmes in the sector. Of the eighty-one programmes reviewed, only thirty-nine (48\%) received full accreditation, with eighteen (22\%) either not accredited at all or 'On Notice of Withdrawal', and the remainder being conditionally accredited. More recent research indicates that curricula continue to miss some of the most important skills teachers need in primary school classrooms, such as the ability to teach reading, writing and basic mathematics to their learners (Taylor 2014). Government is attempting to redress these weaknesses through the promulgation of policy (RSA DHET 2015), but it is doubtful whether policy and regulation, on its own, is an adequate vehicle for raising quality.

Regarding continuous professional teacher development, Armstrong quotes Raudenbush (Raudenbush, Eamsukkawat, Di-lbor et al 1993) on his finding that in-service training does not appear to have any significant effect on student performance, whereas internal supervision (by the school principal or another teacher at the school)' has a large and significant effect. These and similar findings pose questions for current initiatives in South Africa, such as those launched by the National Education Collaboration Trust, and the DBE in the form of its 1+4 Programme. Are we learning from our past mistakes and successes? Are we building a knowledge base to guide better development? Are we designing programmes that draw on past experience and scientific evidence? Or are we merely recycling ideas that have largely not worked in the past?

1 This is in contrast to external supervision by a district official, which shows no significant impact on student performance. 


\section{The availability and quality of data}

In his contribution Chris van Wyk notes that in recent years there has been a considerable expansion in the availability, and in some cases also in the quality, of data available for policy formulation, management decision making and research. It must be said that this development has been an important contributor to the recent upsurge in policy-related research in the school sector. Not only is government commissioning more research, but it is making available data, both to its commissioned service providers and the research community in general. And this is occurring across government departments, making possible the linking of data on a variety of socioeconomic and other indicators.

Van Wyk produces an inventory of data sets available in the terrain of education, details their features, and indicates where they can be found. This is very helpful information for research workers. He goes on to make recommendations for improvements to the accessibility and utility of existing data sets. In particular, Van Wyk recommends that data sets be linked through the standardization of unique institution and individual identifiers.

\section{Conclusion}

The most significant development in South African education since the establishment of the first democratic government in 1994 has been the growth in numbers enrolled at all levels of the system: Grade R, primary and secondary schools, Further Education and Training (FET) colleges and universities (Table 1).

Table 1: Growth in enrolments in education by level

\begin{tabular}{|c|c|c|c|c|c|}
\hline & Grade $\mathbf{R}$ & $\begin{array}{l}\text { Secondary } \\
\text { schools }\end{array}$ & $\begin{array}{c}\text { Colleges and } \\
\text { AET }\end{array}$ & University & Teachers \\
\hline Growth no & 552739 & & 312062 & 428373 & 5050 \\
\hline Growth \% & $244 \%$ & $300 \%$ & $87 \%$ & $82 \%$ & $48 \%$ \\
\hline Period & $2000-13$ & $1970-1995$ & $2010-13$ & $1994-2012$ & $2004-2013$ \\
\hline Source & $\begin{array}{c}\text { RSA DBE } \\
\text { 2011a; } 2013\end{array}$ & $\begin{array}{c}\text { Crouch \& } \\
\text { Vinjevold } \\
2006\end{array}$ & $\begin{array}{c}\text { RSA DHET } \\
2014\end{array}$ & $\begin{array}{c}\text { Taylor, } \\
\text { Fleisch \& } \\
\text { Shindler } \\
\text { 2008; CHE } \\
2014\end{array}$ & CDE 2015 \\
\hline
\end{tabular}

Some of the phenomenal growth in enrolment began under apartheid, particularly with respect to secondary schooling following the Soweto uprising of 1976, and higher education, where an expansion of $73 \%$ was recorded during the seven years leading up to 1994. But growth in Grade R, colleges and universities has exploded since 1994. Such rapid expansion must strain resources, and in particular, the skilled human resources required to deliver quality education. Under the circumstances, a policy question that 
begs asking is: would it not be wise to place a moratorium on further expansion and focus on quality? For example, in pursuing technical and vocational training, why not build centres of true excellence - say, an outstanding FET college in each province - staffed by the best teachers, with excellent facilities, and a student body selected from among poor children exhibiting the highest potential? This would both boost the skilled human resources the country so badly needs, and create role models of children rising out of poverty through the development and exercise of their talent.

Line function ministries tend to avoid such choices, for two main reasons. First, political time horizons are shorter than the time it takes to build successful institutions, and in the meantime budding centres of excellence look like bastions of privilege. Second, the symbolic benefits of providing easily visible resources such as learning places for children, new buildings or computer hardware, tend to obscure, in the short term, the poor quality attendant on such expenditure. ${ }^{2}$ In addition, should it become apparent that the benefits offered by such education are not fulfilled in the market, the public will lose faith in the promise of education to fulfil their aspirations, and that is a frightening prospect. A key element in developing the education system is the importance of having a long-term plan, such as the National Development Plan, to guide government in developing long-term quality goals. And here the work of the Department of Planning, Monitoring and Evaluation is important - in commissioning independent research into key problems of delivery.

These considerations point to a long-standing debate in the field of public policy analysis concerning the relationship between goals that seek to promote equity through spreading resources more equitably across the population, and those that prioritise efficiency (or development), which, classically, were thought to require the concentration of resources. Thus, for makers of public policy, choices were often seen to involve difficult trade-offs between competing policy options serving, respectively, the goals either of equity or efficiency (NEPI 1993). A break with this dichotomy was attempted by the World Bank in 2006, when it declared that:

For many, if not most, people, equity is intrinsically important as a development goal in its own right. But this Report goes further, by presenting evidence that a broad sharing of economic and political opportunities is also instrumental for economic growth and development.

World Bank 2005: 9

Equity and development; we can have both, the Bank confidently asserted, and the achievement of this state would depend on two principles: equality of opportunity, irrespective of the conditions of one's birth; and the avoidance of deprivation in outcomes, particularly in health, education and consumption levels.

2 To its credit, the Department of Basic Education has published a plan for schooling directed towards twenty-seven goals; nine of the thirteen output goals are unequivocally about improving the quality of provision (RSA DBE 2011b). However, problems with the system designed to measure quality is bedevilled with problems of design and perceptions that government is spinning the results, although it is not clear whether this is through ignorance or design. 
Yes, but that is precisely the problem: it is one thing to spread resources relatively equitably across the population; indeed public resources in South Africa have a propoor bias. But it is quite another matter to achieve the second principle on which equity depends: equality of outcomes. The papers in this volume indicate how far the education system is from giving effect to the principle of equality of learning outcomes. Debates about alternative routes to equity are vast and cannot be entered into systematically here, except to make the point that we live in a time of uncertainty regarding many policy issues, most obviously in the field of national and cross-national financial regulation, and environmental control.

Nowhere is this uncertainty better illustrated than in the 2015 World Development Report (World Bank 2015). The title of this Report - 'Mind, Society, and Behavior' captures the idea that paying attention to how humans think and how history and context shape thinking can improve the design and implementation of development policies and interventions that target human choice and action. "To put it differently," the Bank declares, "[...] development policy is due for its own redesign based on careful consideration of human factors" (ibid:2). The details of this new approach sound intellectually exciting, politically inclusive, and plain commonsensical. It also sounds as if the Bank is going back to the drawing board. This is not to hold a candle for the particular approaches, past and present, adopted by the Bank, but to illustrate how uncertain this major player has become about the effects of its own policy advice and funding choices. The 2015 World Development Report concedes that experts, policy makers and development professionals, like everyone else, are subject to the biases and mistakes that can arise from thinking automatically, thinking socially, and using faulty mental models. It recommends that development professionals need to be more aware of these biases, and that organizations should implement plans to ameliorate them.

In this climate, the final advice offered by the 2015 Report (World Bank 2015) is that development practice requires an iterative process of discovery and learning. Careful research, replicated under different conditions, viewed from different angles, is what builds a knowledge base to guide policy. These proposals seem eminently sensible. In the past they have been little practiced in South Africa in the domain of education, but the papers in the present volume indicate that the capacity to undertake policy-related research is expanding. At the same time, a major factor in stimulating policy research in education is the willingness on the part of providers - principally government - to commission such work to private sector and civil society agents and to make information available for secondary analysis.

In conclusion we offer four priorities for policy research in South Africa. First, if primary school teachers are unable to teach literacy and basic numeracy to their learners, there seems little point in attempting any of the other subjects. Yet, it has become as clear as day that the majority of South African teachers are unable to wield either of these skills effectively in their classrooms. It also seems obvious that they should learn these disciplines during their initial teacher education, pointing to a primary quality blockage in the cycle of schooling. Developing effective literacy 
and numeracy programmes that equip new teachers for successful instruction are research and development tasks that only partially intersect with policy research. They will require work on the part of experts in curriculum, pedagogy and assessment, and their achievement will immeasurably enhance the professional status of teaching.

A second priority must be to establish the characteristics of effective school leadership and management, and of successful teaching. There has been much criticism of the Integrated Quality Management Strategy, in the sense that many of the indicators bear no necessary relationship to effective pedagogy or school leadership (RSA DoE 2009). Yet, to date research results in this area have been disappointing. These are also tasks that require the participation of educational experts, in addition to statistical modellers. Effective pedagogy will be determined by the extent to which it achieves success in getting learners to master the curriculum, which links this second priority closely to the first.

A third priority concerns in-service training. Government budgeted R1.1 billion to training in 2014 (RSA DBE 2015). Although only R4.2 million was spent, this is a significant sum. The private sector contributed at least an equivalent amount (Trialogue 2015). But what have we learnt from all this activity, which has been operating at this kind of scale for decades? Not much, is the honest answer. The priority here is not only to evaluate individual programmes, but to systematically build a knowledge base that guides effective policy, programme design and roll-out. Two of the research programmes in this area (Fleisch, Taylor, Schöer \& Mabogoane 2015; Schollar 2015) have both adopted or are adopting a research and development approach. A third example in this important field is the meta-analysis conducted by Besharati and Tsotsotso (2015).

The fourth priority for research into educational policy and practice lies in the field of technology, a key topic not touched on by the contributors to this volume. Technology, in a wide variety of forms, and serving a multitude of uses, is flooding into our schools and classrooms. The inflated expectations attendant upon - and inadequate preparation for - many large initiatives often do not seem to heed the advice of the Organisation for Economic Co-operation and Development (OECD) on the potential of technology to enhance the quality of schooling: "Technology can amplify great teaching, but great technology cannot replace poor teaching” (OECD 2015:190). Technology roll-out comes with many problems that, if not addressed, "may do more harm than good to the teacher-student interactions that underpin deep conceptual understanding and higher order thinking" (ibid). Gauteng is currently in the middle of a second round of technology roll-out, following the failed Gauteng Online programme of a decade ago. Have we learnt any lessons from these efforts? Are we learning from the rapid roll-out of phase two? It seems that the deployment of technology in schools, an inevitable development, would happen most efficiently if accompanied by research of various kinds: design, implementation, process and impact. 


\section{References}

Besharati, N. \& Tsotsotso, K. 2015. In search of the education panacea: A systematic review and comparative meta-analysis of interventions to improve learner achievement in South Africa. Unpublished research report. Johannesburg: University of the Witwatersrand.

CDE (Centre for Development and Enterprise). 2015. Teachers in South Africa: Supply and demand 2013-2025. Johannesburg: Centre for Development and Enterprise.

CHE (Council on Higher Education). 2010. Report on the National Review of Academic and Professional Programmes in Education. HE Monitor, No 11. Pretoria: Council on Higher Education.

CHE. 2014. Vital Stats: Public Higher Education 2012. Pretoria: Council on Higher Education. Retrieved from http://www.che.ac.za/sites/default/files/publications/ VitalStats\%202012\%20Web.pdf (assessed 13 September 2015).

Crouch, L. \& Vinjevold, P. 2006. South Africa: Access before quality, and what to do now? Profesorado, 10(1).

Fleisch, B., Taylor, S., Schöer, V \& Mabogoane, T. 2015. Assessing the impact of the RCUP: A report of the findings of the impact evaluation of the Reading Catch-Up Programme. Johannesburg: Zenex Foundation.

NEEDU (National Education Evaluation and Development Unit). 2013. NEEDU National Report 2012: The State of Literacy Teaching and Learning in the Foundation Phase. Pretoria: National Education Evaluation and Development Unit.

NEEDU. 2014a. NEEDU National Report 2013: Teaching and learning in rural primary schools. Pretoria: National Education Evaluation and Development Unit.

NEEDU. 2014b. NEEDU Reading Study 2013: The state of reading in Grade 5 in selected rural primary schools. Pretoria: National Education Evaluation and Development Unit.

NEPI (National Education Policy Investigation). 1993. National Education Policy Investigation: The Framework Report and Final Report Summaries. Cape Town: Oxford University Press and NECC.

OECD (Organisation for Economic Co-operation and Development). 2015. Students, computers and learning 2015 - Making the connection. Retrieved from http://www. oecd.org/publications/students-computers-and-learning-9789264239555-en.htm (accessed 9 October 2015).

Raudenbush, S.W., Eamsukkawat, S., Di-lbor, I., Kamali, M. \& Taoklam, W. 1993. Onthe-job improvements in teacher competence: Policy options and their effects on teaching and learning in Thailand. Educational Evaluation and Policy Analysis, 15(3):279-297.

Ray, D. 1998. Development Economics. Princeton: Princeton University Press.

RSA DBE (Republic of South Africa. Department of Basic Education). 2011a. Universal Access to Grade R: Policy Framework. Pretoria: Department of Basic Education.

RSA DBE. 2011b. Action plan to 2014: Towards the realisation of Schooling 2025. Pretoria: Department of Basic Education. 
RSA DBE. 2013. School Realities 2013. Pretoria: Department of Basic Education.

RSA DBE. 2015. 2013/14 Annual Report on Training Interventions and 2014/15 Work Skills Plan. Unpublished report. Pretoria: Department of Basic Education.

RSA DHET (Department of Higher Education and Training). 2014. Annual Report 2013/14. Pretoria: Department of Higher Education and Training.

RSA DHET. 2015. Revised Policy on the Minimum Requirements for Teacher Education Qualifications. Department of Higher Education and Training. Government Gazette, No 38487, 19 February 2015. Pretoria: Government Printers.

RSA DoE (Republic of South Africa. Department of Education). 2009. Ministerial Committee on a National Education Evaluation and Development Unit: Final Report. Government Gazette, No 32133, Notice 389 of 2009, 17 April 2009. Pretoria: Government Printers.

Schollar E. 2015. The Primary Mathematics Research Project: 2004-2012: An evidencebased programme of research into understanding and improving the outcomes of mathematical education in South African primary schools. Thesis submitted for the degree of Doctor of Philosophy, Department Of Sociology, University Of Cape Town, January 2015.

Soudien, C. 2008. The implications of the crisis in numeracy and literacy in South Africa for teacher education. Keynote address to the Teacher Education Research and Development Programme (TEP) Conference 2008. Proceedings of the TEP Concluding Conference. Johannesburg: Centre for Education Policy Development. 1-9.

Taylor, N. 2014. An examination of aspects of the BEd curricula for Intermediate Phase teachers at five higher education institutions: Summary Report. Johannesburg: JET Educational Services.

Taylor, N., Fleisch, B \& Shindler, J. 2008. Changes in education since 1994. Paper commissioned by the Policy Unit, Office of the Presidency. Retrieved from www. jet.org.za (accessed 20 October 2015).

Trialogue. 2015. CSI growth slows in 2014. Retrieved from http://trialogue.co.za/csigrowth-slows-in-2014 (accessed 28 April 2015).

Van der Berg, S., Girdwood, E., Shepherd, D., Van Wyk, C., Kruger, J., Viljoen, J., Ezeobi, O. \& Ntaka, P. 2013. The impact of the introduction of Grade R on learning outcomes. Final Full Report for the Department of Basic Education and the Department of Performance Monitoring and Evaluation in the Presidency. Stellenbosch: University of Stellenbosch.

World Bank. 2005. World Development Report 2006: Equity and development. Washington, DC and New York: World Bank and Oxford University Press. Retrieved from http://www-wds.worldbank.org/servlet/WDSContentServer/WDSP/IB/2005 /09/20/000112742_20050920110826/Rendered/PDF/322040WorldoDevelopmento Report02006.pdf (accessed 7 October 2015).

World Bank. 2015. World Development Report 2015. Overview: Human Decision Making and Development Policy. Washington, DC: The World Bank. Retrieved from http:// www.worldbank.org/content/dam/Worldbank/Publications/WDR/WDR\%202015/ Overview-English.pdf (accessed 7 October 2015). 